\title{
Morphological Changes of the Acrosome in Boar Spermatozoa during and after Cell Death
}

\author{
Tsutomu Hashizume, Ichiro Tanimura, and Shigeto Kanematsu \\ Laboratory of Animal Reproduction, Faculty of Agriculture, \\ Iwate University Ueda 3, Morioka-shi 020, Japan
}

(Accepted for publication December 11, 1989)

\begin{abstract}
Summary. The present study was carried out to clarify morphological changes of acrosome in boar sperm heads during and after cell death. Undiluted boar semen was incubated at $37{ }^{\circ} \mathrm{C}$ under aerobic condition for 5 or $10 \mathrm{hr}$ and the sperm head morphology was observed by a transmission electron microscopy. The viability of boar spermatozoa just before incubation was very vigorous, but $98 \%$ of the spermatozoa was completely immotile within $5 \mathrm{hr}$ after the start of incubation. Most of the spermatozoa $(81.1 \%)$ just before incubation showed normal structures of the head. The normality of sperm head morphology remarkably decreased $(8.1 \%) 5 \mathrm{hr}$ after incubation $(\mathrm{P}<0.05)$, and the morphology of membrane vesiculation $(41.8 \%)$ and swelling of plasma membrane $(28.1 \%)$ increased $(\mathrm{P}<0.05)$. In contrast to the results $5 \mathrm{hr}$ after incubation the membrane vesiculation $(10.5$ $\%)$ and the swelling of plasma membrane $(4.1 \%)$ decreased $(\mathrm{P}<0.05) 10 \mathrm{hr}$ after the incubation, and loss of acrosomal contents $(52.6 \%)$ remarkably increased $(\mathrm{P}<0.05)$. It was suggested that a swelling of plasma membrane, membrane vesiculation and loss of acrosomal contents might mainly participate in the course of morphological changes of acrosome in boar sperm heads during and after cell death.
\end{abstract}

KEY WORDS: ACROSOME, AGING, BOAR SPERMATOZOA, ULTRASTRUCTURE.

Jpn J Anim Reprod 36, 35-40, 1990

The acrosome on the heads of mammalian spermatozoa possesses enzymes participated in fertilization (Mann and Lutwak-Mann, 1981; Yanagimachi, 1988), and morphological abnormality of this region reduces fertility in domestic animals (Bane and Nicander, 1966; Andersen, 1974; Uwland, 1984). Therefore, it is important to understand the morphological abnormality of this region at the time of the practice of artificial insemination in domestic animals. The morphological changes of the acrosome in ejaculated spermatozoa appeared by aging, cold shock, freezing-thawing, osmotic changes, dilution or repeated centrifugation and washing (Mann and Lutwak-Mann, 1981), exclusive of morphological changes during the course of fertilization (Bedford, 1970; Yanagimachi, 1988).

Routine examinations of morphological abnormalities of the acrosome for the artificial insemination have been done mainly by a light microscopic technique in boar spermatozoa (Onuma, 1963; Pursel et al., 1972; Pursel, 1979; Niwa et al., 1981; Niwa and Hashizume, 1981). In these studies, the acrosomes were assessed after fixation and Giemsa staining and evaluated at $\times 1,500$ with a light microscopy (Onuma, 1963; Niwa et al., 1981; Niwa and Hashizume, 1981) or were assessed directly without fixation and staining by a phasecontrast microscopy (Pursel et al., 1972; Pursel, 1979). However, these techniques have difficulties in understanding the morphological abnormality of the acrosome. Especially, in order to elucidate changes of membrane structures and inner acrosome structures, it is required to observe these structures with a transmission electron microscopy (TEM). A few reports on morphological changes of the acrosome using the TEM during preservation of boar semen have been published 
Table 1. Morphological changes of boar sperm head after incubation at $37^{\circ} \mathrm{C}$ for 5 and $10 \mathrm{hr}$

\begin{tabular}{|c|c|c|c|c|}
\hline \multirow{2}{*}{$\begin{array}{l}\text { Morphology of } \\
\text { sperm head }\end{array}$} & & \multicolumn{3}{|c|}{ Incubation period } \\
\hline & & $0 \mathrm{hr}$ & $5 \mathrm{hr}$ & $10 \mathrm{hr}$ \\
\hline & & \multicolumn{3}{|c|}{ Appearance rates (\%) } \\
\hline Intact & (Fig. 1) & $81.1 \pm 3.1^{\mathrm{a}}$ & $8.1 \pm 3.0^{\mathrm{b}}$ & $5.9 \pm 1.8^{\mathrm{b}}$ \\
\hline $\begin{array}{l}\text { Swelling of plasma } \\
\text { membrane }\end{array}$ & (Fig.2) & $3.6 \pm 0.8^{\mathrm{a}}$ & $28.1 \pm 5.2^{\mathrm{b}}$ & $4.1 \pm 0.5^{\mathrm{a}}$ \\
\hline $\begin{array}{l}\text { Swelling of } \\
\text { acrosome }\end{array}$ & (Fig.3) & $5.2 \pm 0.1$ & $11.5 \pm 6.9$ & $5.6 \pm 1.6$ \\
\hline $\begin{array}{l}\text { Loss of acrosomal } \\
\text { contents }\end{array}$ & (Fig.4) & $3.1 \pm 1.6^{\mathrm{a}}$ & $2.0 \pm 1.8^{\mathrm{a}}$ & $52.6 \pm 11.1^{\mathrm{b}}$ \\
\hline $\begin{array}{l}\text { Membrane } \\
\text { vesiculation }\end{array}$ & (Fig.5) & $0^{\mathrm{a}}$ & $41.8 \pm 7.8^{b}$ & $10.5 \pm 8.2^{\mathrm{a}}$ \\
\hline $\begin{array}{l}\text { Break or loss of } \\
\text { plasma membrane }\end{array}$ & (Fig.6) & $0^{\mathrm{a}}$ & $6.8 \pm 1.5^{\mathrm{b}}$ & $4.4 \pm 0.6^{b}$ \\
\hline $\begin{array}{c}\text { Swelling of plasma and } \\
\text { acrosomal membrane }\end{array}$ & (Fig.7) & 0 & $1.7 \pm 1.0$ & $16.9 \pm 13.3$ \\
\hline
\end{tabular}

More than 100 of spermatozoa from each ejaculate of 3 boars were observed with a TEM at a magnification of $\times 5,000$ and the results (Appearance rates) were expressed as the mean \pm S.E. of 3 ejaculates from 3 boars. The mean percentages of motile spermatozoa was 80 just before incubation $(0$ $\mathrm{hr}$ ), but it decreased to 2 and 1 after incubation for 5 and $10 \mathrm{hr}$.

$\mathrm{a}, \mathrm{b}:$ Different letters on the same line indicate a significant difference $(\mathrm{P}<0.05)$.

(Jones, 1973; Niwa et al., 1981; Bamba and Cran, 1985; Courtens and Paquignon, 1985) and heretofore, no morphological change of that during aging, especially after cell death, has been reported in boar spermatozoa.

In the present study, morphological changes of the acrosome in boar spermatozoa during and after cell death were examined by using the TEM to find a clue to the morphological changes of that during preservation of boar semen more in detail.

\section{Materials and Methods}

Boar semen was collected by an artificial vagina from normal 2 Large White and 1 Landrace boars. The colloidal fractions in whole semen were removed by filtering through a double gauze. A $2 \mathrm{ml}$ semen was transferred to a $10 \mathrm{ml}$ test tube and the semen was incubated for 5 or $10 \mathrm{hr}$ at $37{ }^{\circ} \mathrm{C}$ under aerobic conditon. Collections of samples for motility and acrosomal evaluations were carried out just before incubation and 5 or $10 \mathrm{hr}$ after incubation. The motility of spermatozoa was estimated microscopically at $37^{\circ} \mathrm{C}$. Samples for the TEM and observations of the acrosome were processed as follows. The spermatozoa were fixed with cold $2 \%$ glutaraldehyde in $0.1 \mathrm{M}$ phosphate buffer (pH 7.2) for $1.5 \mathrm{hr}$ and followed by fixation with cold 1 $\%$ osmium tetroxide in $0.14 \mathrm{M}$ veronal acetate buffer for $1.5 \mathrm{hr}$. After dehydration with a graded series of ethyl alcohol, the spermatozoa were embedded in Epon. Sections were cut with glass knives on an ultramicrotome. Ultra thin sections were stained with lead citrate and uranyl acetate and examined with a Hitachi $\mathrm{H}-800$ electron microscope at $100 \mathrm{kV}$. Observations of the acrosome were first carried out at the magnification of more than $\times 5,000$ (initial magnification) and the type of structural changes occurring in the acrosome was examined. Then low power (initial magnification, $\times 2,000$ ) electron micrographs of different areas of the section were taken randomly. Prints (photographic enlargement, $\times 2.5$ ) were examined and all the sections of sperm heads through appropriate planes were classified according to the type of structural changes occurring in the acrosome. More than 100 sections of sperm heads were observed in each ejaculate of 3 boars and appearance rates of each morphological type in the 


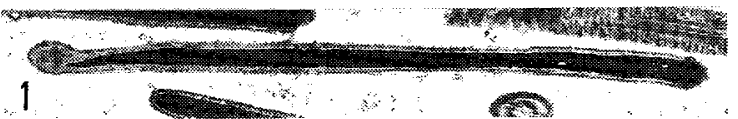

Fig. 1. Intact: A sagittal section of a normal boar sperm head. The intact plasma membrane overlying an undamaged normal acrosome can be seen. $\times 13,000$.

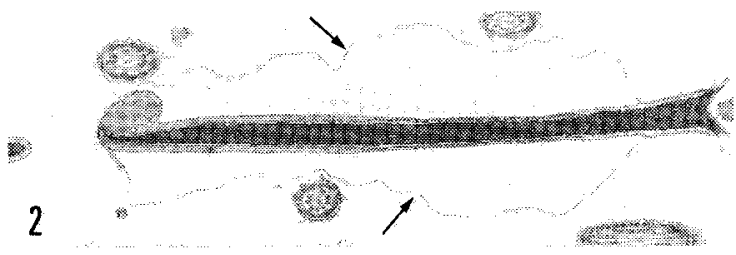

Fig. 2. Swelling of plasma membrane: Plasma membrane swells (arrows) and the space occurs between the plasma and outer acrosomal membrane. $\times 14,000$.

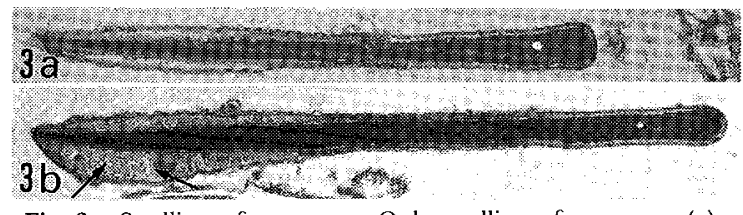

Fig. 3. Swelling of acrosome: Only swelling of acrosome (a) or vesicles (arrows) are formed within the swollen acrosome (b). $\times 16,000(a), \times 15,000$ (b).

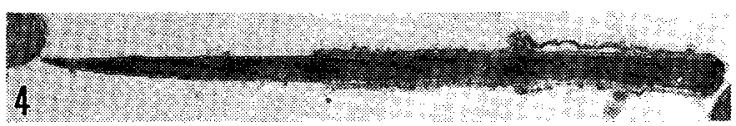

Fig. 4. Loss of acrosomal contents: Lacking of the acrosomal contents and a nucleus is exposed. $\times 14,000$.

acrosome were calculated.

The statistical significance of differences in appearance rates of each morphological type during incubation period was analyzed by a Duncan's new multiple range test. Data were expressed as means and standard errors.

\section{Results}

The viability of boar spermatozoa just before incubation was very vigorous (mean percentage of motile spermatozoa; $80 \%$ ), but it was rapidly reduced after 5 $\mathrm{hr}$ incubation (mean percentage of motile spermatozoa; $2 \%$ ). No significant difference in the viability of spermatozoa was seen between the 5- and $10 \mathrm{hr}$ incubation groups.

The morphological changes of boar sperm heads after incubation at $37^{\circ} \mathrm{C}$ were classified into 7 groups as

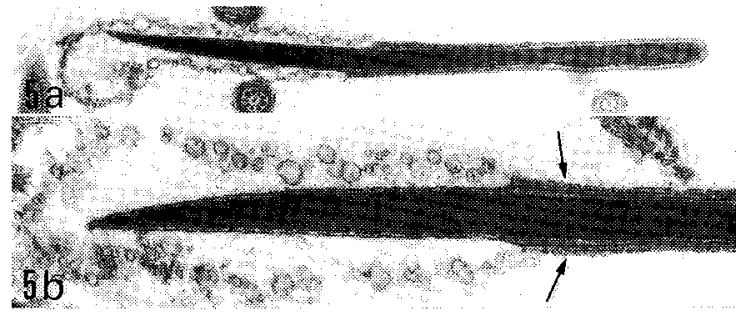

Fig. 5. Membrane vesiculations: Membrane vesiculation resulting from fusing of the plasma membrane and the outer acrosomal membrane is seen in the acrosomal cap region (a). Acrosomal contents are lacking. The vesiculation is also observed in the equatorial segment (arrows), but the vesiculation is small and sticks to the nucleus in this region (b). $\times 14,000$ (a), $\times 28,000$ (b).

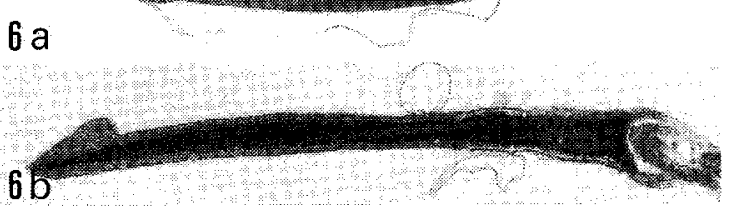

Fig. 6. Break or loss of plasma membrane: A cross-section (a) showing broken plasma membrane and the formation of the whorls (arrows). A sagittal section (b) showing loss of the plasma membrane overlying the acrosome. $\times 19,000$ (a), $\times 17,000$ (b).

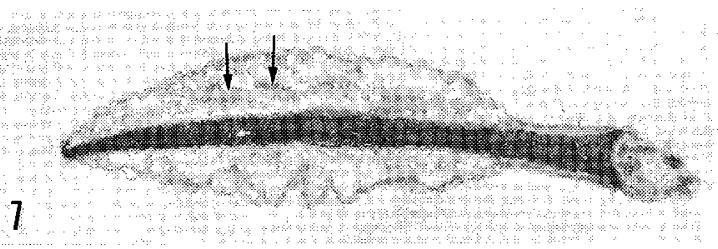

Fig. 7. Swelling of plasma and acrosomal membrane: Swelling of plasma and acrosomal membrane and acrosomal contents are dispering. Microtuble like structures (arrows) can be seen. $\times 13,000$.

shown in Figs. 1-7. The appearance rates of these spermatozoa after incubation are shown in Table 1. Most of spermatozoa $(81.1 \%)$ just before incubation showed normal structures of the head (Fig. 1). Abnormal morphology of the head observed just before incubation consisted of swelling of plasma membrane (3.6\%, Fig. 2), swelling of acrosome (5.2\%, Fig. 3) and loss of acrosomal contents $(3.1 \%$, Fig. 4$)$. The normality of sperm head morphology decreased to $8.1 \% 5 \mathrm{hr}$ after incubation $(\mathrm{P}<0.05)$, and membrane vesiculations 
(41.8\%, Fig. 5) and the swelling of the plasma membrane $(28.1 \%)$ remarkably increased $(\mathrm{P}<0.05)$. Break or loss of the plasma membrane (Fig. 6) also appeared $5 \mathrm{hr}$ after incubation $(\mathrm{P}<0.05)$, but the appearance rate was low $(6.8 \%)$. In contrast to the results $5 \mathrm{hr}$ after incubation, membrane vesiculations (10.5\%) and the swelling of the plasma membrane (4.1 $\%)$ decreased $(\mathrm{P}<0.05) 10 \mathrm{hr}$ after incubation, and the loss of acrosomal contents $(52.6 \%)$ remarkably increased $(\mathrm{P}<0.05)$. The swelling of the acrosome and swelling of plasma and acrosomal membranes (Fig. 7) were observed in the 5- and 10-hr incubation groups, without any significant change in appearance rates during the incubation period.

\section{Discussion}

The prominent morphological changes that appeared after $5 \mathrm{hr}$ incubation at $37^{\circ} \mathrm{C}$ were swelling of the plasma membrane and membrane vesiculations; especially the rates of the latter were more prominent. Yanagimachi and Noda (1970) reported that when hamster epididymal spermatozoa were incubated in an unsupplemented physiological solution at $38{ }^{\circ} \mathrm{C}, 90 \%$ or more of the spermatozoa was completely immotile within $5 \mathrm{hr}$ after the start of incubation and that electron micrographs of these spermatozoa often showed a swelling of plasma membrane. But they failed to observe the membrane vesiculation, which was observed in our experiment. Jones and Martin (1973) also reported that incubation of undiluted ram semen at $35^{\circ} \mathrm{C}$ for $2 \mathrm{hr}$ caused a highly significant depression in sperm motility. In their report, $7 \%$ of membrane vesiculation and $38.5 \%$ of abnormal plasma membrane spermatozoa were observed. Therefore, it is suggested that a phenomenon of the membrane vesiculation during and after cell death may depend on animal species. The membrane vesiculations are usually observed in motile spermatozoa during a course of acrosome reaction (Bedford, 1970; Yanagimachi, 1988). Bedford (1970) distinguished the acrosome reaction into true or false reaction depending on morphological features of the acrosome. The membrane vesiculation obseved in the present study differed from false reaction in his classification. In addition, no morphological difference in the membrane vesiculation was observed in the present study in comparison with that observed in boar spermatozoa after recovering from the uterus (Jones, 1973), at the time of fertilization (Szöllösi and Hunter, 1978) and chemically inducing the acrosome reaction (Peterson et al., 1978). Therefore, further detailed studies are necessary to clarify the morphological differences in the membrane vesiculation originated from physiological and not physiological factors.

The frequency of the swelling of the plasma membrane and the membrane vesiculation were reduced 10 hr after incubation with a rapid loss of acrosomal contents. The morphology of the loss of acrosomal contents was observed in as much as $52 \%$ of spermatozoa after 10 -hr incubation. Therefore, the morphological changes observed were supposed to be the final stage during the course of sperm death. They seem to result from the membrane vesiculation because the vesiculation rate was high $5 \mathrm{hr}$ and decreased rapidly 10 hr after incubation. The swelling of the plasma membrane was considered to be the morphological change, which appeared at the comparatively early stage of the course of sperm death, because the rate of this morphological change at 5-hr incubation was higher than that at 10 -hr incubation and the change could be seen even just before incubation at $37^{\circ} \mathrm{C}$. Collection of samples started after 5-hr incubation in the present study, and it is considered that morphological changes in the sperm head will be found more clearly by taking samples within $5 \mathrm{hr}$ after incubation.

A break or loss of the plasma membrane appeared both 5 and $10 \mathrm{hr}$ after incubation with the low appearance rate. The same morphological change was observed in some of submortem or postmortem hamster spermatozoa in the uterus (Yanagimachi and Noda, 1970). The morphological changes seemed to result from a breaking of swelling of the plasma membrane by some factors relation to the structural features (Fig. 6a).

There was no significant change in the appearance rate of the swelling of the acrosome and the swelling of plasma and acrosomal membrane during the incubation period. Both cooling to $5^{\circ} \mathrm{C}$ and inclusion of glycerol in the $5{ }^{\circ} \mathrm{C}$ diluents were reported to increase the swelling of acrosome in boar spermatozoa (Jones, 1973). The same morphological changes were observed in frozenthawed boar spermatozoa (Niwa et al., 1981; Bamba and Cran, 1985; Courtens and Paquignon, 1985). It was found that the morphological changes observed by these authors could occur in a minor degree even without using any special treatments in the present study. It was also reported that a vacuolation in swollen acrosome occurred with a rapid swelling of the acrosome (Jones,1973). The swelling of plasma and acro- 
somal membrane was also observed in frozen-thawed boar spermatozoa incubated for $3 \mathrm{hr}$ at $37{ }^{\circ} \mathrm{C}$ in vitro (Bamba and Cran, 1985). Therefore, it was considered to occur at comparatively shorter time after incubation at $37^{\circ} \mathrm{C}$ in frozen-thawed semen compared with fresh semen.

These results suggest that the light microscopic approach (Onuma,1963; Pursel et al., 1972; Pursel, 1979; Niwa et al., 1981; Niwa and Hashizume, 1981) may have difficulty in elucidating morphological changes of boar sperm head compared with the present technique of a TEM. The morphological changes of boar sperm head in the present study occurred under warm $\left(37^{\circ} \mathrm{C}\right)$, aerobic condition in contact with seminal plasma. Boar spermatozoa also died out when the undiluted spermatozoa were given a cold shock or freezing-thawing. Further comparative studies in consideration of these conditions are neccessary to clarify the morphological changes of the acrosome in boar spermatozoa during and after cell death.

\section{Acknowledgments}

The authors wish to thank professor emeritus $T$. Niwa, Iwate University for his helpful advise and encouragement. This work was partly supported by a Grant-in-Aid for Scientific Reserch (63760210) from the Ministry of Education, Science and Culture, Japan.

\section{References}

Andersen K (1974) Morphological abnormalities in the acrosome and nucleus of boar spermatozoa. Nord Vet-Med 26: 215-218.

Bamba K, Cran DG (1985) Effect of rapid warming of boar semen on sperm morphology and physiology.J Reprod Fert 75: 133-138.

Bane A, Nicander L (1966) Electron and light microscopical studies on spermateliosis in a boar with acrosome abnormality. J Reprod Fert 11: 133-138.

Bedford JM (1970) Sperm capacitation and fertilization in mámmals. Biol Reprod (suppl) 2: 128-158.

Courtens JL, Paquignon M (1985) Ultrastructure of fresh, frozen, and frozen-thawed spermatozoa of the boar. Proc 1 st Intern Confer on Deep Freezing of Boar Semen, Uppsala. pp 61-87.

Jones RC (1973) Changes occurring in the head of boar spermatozoa: Vesiculation or vacuolation of the acrosome ? J Reprod Fert 33: 113-118.

Jones RC, Martin ICA (1973) The effects of dilution, egg yolk and cooling to $5^{\circ} \mathrm{C}$ on the ultrastructure of ram spermatozoa. J Reprod Fert 35: 311-320.

Mann T, Lutwak-Mann C (1981) Biochemistry of spermatozoa: Chemical and functional correlations in ejaculated semen, andrological aspects. In : Male reproductive function and semen, Springer-Verlag, Berlin, Heidelberg, New York. pp 152-268.

Niwa T, Ito K, Loo L-S, Hashizume T (1981) Studies on the deep freezing storage of boar spermatozoa by pelleting method 1. Methods for freezing and thawing. Bull Lab Iwate Univ 1: 66-84 (in Japanese).

Niwa $T$, Hashizume $T$ (1981) Studies on deep freezing storage of boar semen by pelleting method II. Viability of spermatozoa and morphology of spermatozoan acrosome after thawing. Bull Lab AI Iwate Univ 3: 1-8 (in Japanese).

Onuma H (1963) Studies on the acrosomic system of spermatozoa of domestic animals VI. The acrosomic system of spermatozoa in fresh semen of bulls and boars and its morphological changes due to the storage or temperature shock. Bull Nat Inst Anim Ind 3: 105-119 (in Japanese).

Peterson R, Russell L, Bundman D, Freund M (1978) Presence of microfilaments and tubular structures in boar spermatozoa after chemically inducing the acrosome reaction. Biol Reprod 19: 459-466.

Pursel VG, Johnson LA, Rampacek GB (1972) Acrosome morphology of boar spermatozoa incubated before cold shock. J Anim Sci 34: 278-283.

Pursel VG (1979) Advances in preservation of swine spermatozoa. In : Animal Reproduction, BARC Symposium No 3, (Hawk H ed), Osmum \& Co Ltd, Montclair, New Jersey, Allanheld. pp 145-157.

Szöllösi D, Hunter RHF (1978) The nature and occurrence of the acrosome reaction in spermatozoa of the domestic pig, Sus scrofa. J Anat 127: 33-41.

Uwland J (1984) Possibilities and limitations of semen evaluation for the prognosis of male fertility. In: The male in farm animal reproduction, (Courot $\mathrm{M}$ ed), Martinus Nijhoff Publishers, Boston, Dordrecht, Lancaster. pp 269-289.

Yanagimachi R, Noda YD (1970) Fine structure of the hamster sperm head. Am J Anat 128: 367-388.

Yanagimachi R (1988) Mammalian fertilization. In: The physiology of Reproduction, (Knobil E et al., eds), Paven Press Ltd, New York. pp 135-185. 


\title{
豚精子の死滅過程に伴う先体部の形態変化
}

\author{
橋爪 力. 谷村 一郎・兼松 重任 \\ 岩手大学農学部家畜繁殖学講座
}

豚精子の死滅過程に伴う先体部の形態变化を明らかに するために, 豚精液を無希釈の状態で $37^{\circ} \mathrm{C}$ 下に 5 および 10時間インキュベートして, 透過型電子顕微鏡により精 子頭部の形態を観察した。インキュベート直前の精子の 運動性はきわめて良好であったが，インキュベート5時 間後にはほとんどの精子が運動を停止していた。インキ ュベート直前の精子頭部は $81.1 \%$ の精子が正常で, その 他わずかに原形質膜が膨化した精子 $(3.6 \%)$ ，先体部が 膨化した精子（5.2\%）および先体内容物の欠損した精 子 $(3.1 \%)$ が観察された。インキュベート5時間後には
正常精子は急激に減少 $(8.1 \%)$ し $(\mathrm{P}<0.05)$, 原形質 膜の小胞化 (41.8\%) および膨化（28.1\%）した精子が 急増した $(\mathrm{P}<0.05)$ 。10時間後には5 時間後に比へ原形 質膜の小胞化した精子（10.5\%）および膨化した精子 $(4.1 \%)$ が減少し $(\mathrm{P}<0.05)$, 先体内容物の消失した精 子が急増（52.6\%）した $(\mathrm{P}<0.05)$ 。

以上の結果から, 豚精子の死滅過程における精子先体 部の主たる形態変化には原形質膜の膨化, 小胞化抒よび 先体内容物の消失の過程が関与していることが明らかに なった。 